\title{
ВСТАНОВЛЕННЯ ЕФЕКТИВНОї ДОЗИ РІДКОГО ЕКСТРАКТУ ЛІЩИНИ ЗВИЧАЙНОї ЛИСТЯ ТА ДОСЛІДЖЕННЯ ЙОГО АНТИОКСИДАНТНОЇ АКТИВНОСТІ
}

\author{
๑Ю. А. Федченкова', Л. С. Фіра², О. П. Хворост³ , К. С. Скребцова ${ }^{3}$ \\ ${ }^{1}$ Ніжинський державний університет імені Миколи Гоголя \\ ${ }^{2}$ Тернопільський начіональний медичний університет імені І. Я. Горбачевського МОз України \\ ${ }^{3}$ Національний фармацевтичний університет, Харків
}

PЕЗЮМЕ. На сучасному етапі використовується значна кількість лікарських препаратів, які спроможні впливати на окиснювальні процеси в організмі за різних патологічних станів. Проте пошук нових високоефективних та малотоксичних препаратів триває. Ліщина звичайна - поширена рослина вітчизняної флори, листя якої широко використовують як протизапальний та судинозміцнювальний засіб. Актуальним є дослідження антиоксидантної дії оригінального вітчизняного фітозасобу - рідкого екстракту ліщини звичайної листя.

Мета - визначити мінімальну діючу дозу рідкого екстракту ліщини звичайної листя та вивчити його антиоксидантні властивості на моделі токсичного ураження печінки щурів.

Матеріал і методи. Експерименти проведені на білих щурах-самцях з дотриманням усіх правил роботи 3 хребетними тваринами. Токсичне ураження печінки моделювали шляхом введення в організм щурів 50 \% розчину тетрахлорметану в дозі 1,0 мл/кг маси тіла. Рідкий екстракт з ліщини листя тварини отримували в дозі 0,05, 0,1 та 0,2 мл/кг маси тіла. Розвиток оксидативного стресу вивчали за вмістом ТБК-активних продуктів, церулоплазміну та каталазною активністю. Активність цитолітичних процесів досліджували за еритроцитарним індексом інтоксикації та активністю амінотрансфераз в ураженому організмі.

Результати. Встановлено, що ураження печінки щурів тетрахлорметаном призводить до активації процесів ліпопероксидації, на що вказують підвищення у сироватці крові та печінці тварин вмісту ТБК-активних продуктів та зміни показників антиоксидантної системи (підвищення вмісту церулоплазміну в сироватці крові та зниження каталазної активності). За умов ураження підвищувалась активність амінотрансфераз у сироватці крові і, відповідно, знижувалась у печінці токсикованих тварин, що вказує на цитоліз гепатоцитів після ураження печінки щурів тетрахлорметаном.

Застосування рідкого екстракту ліщини звичайної листя в дозі 0,2 мл/кг проявило ефективний вплив на досліджувані показники, наближаючи їх до рівня щурів інтактного контролю. Дози 0,05 та 0,1 мл/кг виявились неефективними щодо досліджуваних показників.

Висновки. Встановлена мінімально діюча доза рідкого екстракту ліщини листя - 0,2 мл/кг маси тварин, яка проявила виражені антиоксидантні властивості за умов токсичного гепатиту в щурів.

КЛючовІ СлОВА: умовно терапевтична доза; токсичний гепатит; антиоксидантна дія; рідкий екстракт ліщини звичайної; листя.

Вступ. Ліщина звичайна Corylus avellana L. широко розповсюджений чагарник чи невелике дерево [12, 22]. Нами проведено фармакогностичне дослідження листя цієї рослини з розробкою монографії ДФУ 2.0 «Ліщини листя» [1]. 3 цього виду сировини в Національному фармацевтичному університеті створено оригінальний лікарський засіб - рідкий екстракт [11] з венотропною активністю. Зважаючи на те, що антиоксидантна дія притаманна сировині поширених представників роду Corylus $L$. [13-14, 16, 19, 22], у тому числі й ліщині звичайній $[15,18,23]$, ми вирішили дослідити антиоксидантну активність цього лікарського засобу, попередньо встановивши його умовно терапевтичну дозу.

Мета - встановити мінімально діючу дозу рідкого екстракту ліщини звичайної листя та вивчити його антиоксидантні властивості на моделі токсичного ураження печінки щурів.

Матеріал і методи дослідження. Дослідження проведено на 60 статевозрілих білих щу-

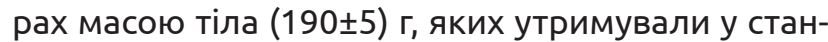
дартних умовах віварію ТНМУ імені І. Я. Горбачевського. Всі маніпуляції з експериментальними тваринами здійснювали із дотриманням правил «Європейської конвенції про захист хребетних тварин, що використовуються для дослідних та інших наукових цілей», а також згідно з «Науковопрактичними рекомендаціями з утримання лабораторних тварин та роботи з ними» [17].

Рідкий екстракт (PE) листя ліщини звичайної одержали за загальновідомими методиками у 2018 році.

Для підбору мінімально діючої дози рідкого екстракту щурів поділили на 5 груп (по 6 тварин у кожній). Одна група слугувала інтактним контролем (IК). Другій групі тварин вводили тетрахлорметан дворазово (через день) у дозі 1,0 мл/кг маси тіла (група контролю (КП)) [7]. Наступним 3 групам на тлі ураження (після моделювання гепатиту) щоденно вводили рідкий екстракт ліщини звичайної листя у різних (0,05 мл, 0,1 мл, 0,2 мл) дозах. Актив- 
Огляди літератури, оригінальні дослідження, погляд на проблему, випадок з практики, короткі повідомлення ність процесів ліпопероксидації в організмі тварин оцінювали за вмістом ТБК-активних продуктів (ТБК-АП) [8], стан антиоксидантної системи - за вмістом церулоплазміну (ЦП) [3] та активністю каталази (КТ) [6], розвиток цитолітичного синдрому - за активністю амінотрансфераз (АсАТ, АлАТ) [20] та еритроцитарним індексом інтоксикації (EII) [10].

Евтаназію тварин проводили під тіопенталовим наркозом на 4 добу розвитку токсичного гепатиту (токсикогенна фаза). Досліджували кров, сироватку крові та печінку щурів.

Отримані експериментальні дані статистично обробляли методом варіаційної статистики з використанням стандартного пакета статистичної програми «Statistica 6.0». Визначали середньоквадратичні відхилення, дисперсію та інші статистичні параметри, а розрахунки похибок вимірювання встановлювали з використанням t-критерію Стьюдента. Зміни вважали вірогідними при $p \leq 0,05$ [21].

Результати й обговорення. Реалізація дії більшості токсичних агентів здійснюється універсальним механізмом - активацією вільнорадикальних процесів. Реакції вільнорадикального окиснення біомолекул відіграють, згідно з сучасними уявленнями, провідну роль у розвитку процесів хімічного ушкодження гепатоцитів за інтоксикації організму ксенобіотиками [5].

Ураження печінки тварин підвищеними дозами тетрахлорметану призводить до активації вільнорадикальних процесів, унаслідок чого в організмі накопичуються вторинні продукти перекисного окиснення ліпідів. Це підтверджується при визначенні вмісту ТБК-АП.

Як видно з таблиці 1, введення тетрахлорметану в організм тварин призводить до суттєвого підвищення вмісту ТБК-активних продуктів. На 4 добу гепатиту цей показник у сироватці крові після ураження зріс в 1,5 раза відносно інтактних тварин $(p \leq 0,05)$. Застосування різних доз рідкого екстракту привело до нормалізації вмісту проміжних продуктів ліпопероксидації, але вірогідно знизився він тільки при введенні дози 0,2 мл/кг. У цій групі щурів вміст ТБК-АП знизився на $31 \%$, порівняно з ураженими тетрахлорметаном тваринами. Доцільним виявилось дослідити вміст ЦП та активність КТ - основних ензимів, які беруть участь в антиоксидантному захисті організму від токсичних продуктів переокиснення, причому ЦП діє на початкових етапах (він $є$ пасткою ОН-радикалів) за умов активації вільнорадикальних процесів, а КТ $є$ одним із кінцевих антиоксидантів, який розщеплює токсичний для організму гідрогену пероксид [2].

Таблиця 1. Вплив різних доз рідкого екстракту ліщини звичайної на біохімічні показники у сироватці крові щурів,

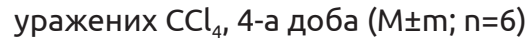

\begin{tabular}{|c|c|c|c|c|c|c|}
\hline \multirow[b]{2}{*}{ Група тварин } & \multicolumn{5}{|c|}{ Показники } & \multirow{2}{*}{$\begin{array}{l}\text { Ell, \% } \\
\text { (кров) }\end{array}$} \\
\hline & $\begin{array}{c}\text { ТБК-АП } \\
\text { мКмоль/л }\end{array}$ & $\begin{array}{l}\text { ЦП } \\
\text { г/л }\end{array}$ & $\begin{array}{c}\mathrm{KT} \\
\text { мКат/л }\end{array}$ & $\begin{array}{c}\text { АлАТ, } \\
\text { мкмоль/л год }\end{array}$ & $\begin{array}{c}\text { АсАТ } \\
\text { мкмоль/л год }\end{array}$ & \\
\hline IK & $2,81 \pm 0,15$ & $8,05 \pm 0,45$ & $6,05 \pm 0,22$ & $0,24 \pm 0,011$ & $0,16 \pm 0,009$ & $26,50 \pm 1,30$ \\
\hline КП & $4,13 \pm 0,12 *$ & $12,36 \pm 0,52 *$ & $5,25 \pm 0,18^{*}$ & $0,36 \pm 0,016^{*}$ & $0,22 \pm 0,010^{*}$ & $54,70 \pm 1,90 *$ \\
\hline КП+0,05 мл/Кг РЕ & $4,02 \pm 0,13$ & $11,54 \pm 0,38$ & $5,64 \pm 0,21$ & $0,32 \pm 0,013$ & $0,22 \pm 0,008$ & $51,30 \pm 1,70$ \\
\hline КП+0,1 мл/кг РЕ & $3,75 \pm 0,12$ & $10,78 \pm 0,42$ & $5,87 \pm 0,19$ & $0,31 \pm 0,012$ & $0,20 \pm 0,010$ & $45,50 \pm 2,00 * *$ \\
\hline КП+0,2 мл/кг РЕ & $3,25 \pm 0,14 * *$ & $9,15 \pm 0,35 * *$ & $6,00 \pm 0,20 * *$ & $0,28 \pm 0,011$ ** & $0,17 \pm 0,008 * *$ & $32,80 \pm 1,20 * *$ \\
\hline
\end{tabular}

Примітки: 1. * - вірогідні зміни між інтактними та ураженими тваринами;

2. ** - вірогідні зміни між ураженими та лікованими тваринами

Після ураження щурів тетрахлорметаном у сироватці крові на 4 добу експерименту вірогідно $(p \leq 0,05)$ зростав вміст цП і на $53 \%$ перевищував рівень інтактного контролю. При введенні ураженим щурам рідкого екстракту в дозі 0,05 мл/кг та 0,1 мл/кг спостерігалась тенденція до зниження вмісту цього антиоксиданта. Доза 0,2 мл/кг ефективно впливала на вміст ЦП і зменшила його на $40 \%(p \leq 0,05)$, порівняно з ураженими тваринами, що виявилось лише на $13 \%$ вище рівня норми.

Ми відмітили зниження каталазної активності на $13 \%$ у сироватці крові щурів на 4 добу тетрахлорметанового гепатиту. Використання рідкого екстракту позитивно впливало на даний ен- зим. Ефективною виявилась доза 0,2 мл/кг маси тіла, після застосування якої каталазна активність була практично на рівні інтактного контролю.

Активація окиснювальних процесів та пригнічення активності системи антиоксидантного захисту за умов ураження печінки тетрахлорметаном призводить до нагромадження токсичних продуктів, які чинять пошкоджувальний вплив на мембрани клітин [4], що призводить до їх цитолізу.

Після ураження тетрахлорметаном активність АлАТ у сироватці крові збільшилась у 1,5 раза, активність АсАТ - у 1,4 раза (табл. 1). Дози 0,05 мл/кг та 0,1 мл/кг не мали ефективного впливу на активність амінотрансфераз. Мінімальною діючою 
Огляди літератури, оригінальні дослідження, погляд на проблему, випадок з практики, короткі повідомлення дозою виявилась доза 0,2 мл/кг, яка вірогідно ( $\leq \leq 0,05)$ знизила активність ензимів, наближаючи їх до рівня інтактного контролю. Аналогічна тенденція відмічена щодо проникності еритроцитарної мембрани. Ураження щурів тетрахлорметаном викликало збільшення Ell з 26,5 \% до 54,7 \%, тобто на 28,2 \%. Введення рідкого екстракту в двох дозах (0,1 мл/кг та 0,2 мл/кг) привело до нормалізації проникності еритроцитарної мембрани. Відсоток її проникності знизився на 9,2 \% та 21,9 \% відповідно. Аналізуючи отримані показники сироватки крові після ураження щурів тетрахлорметаном та застосування різних доз рідкого екстракту для корекції виявлених порушень можна констатувати, що на процеси вільнорадикального окиснення, активність антиоксидантної системи

та мембранодеструктивних процесів в ураженому організмі ефективно впливала доза 0,2 мл/кг маси тіла щурів.

Відомо, що тетрахлорметан $\epsilon$ гепатотропною отрутою, його потрапляння до організму викликає ураження печінки, з чим пов'язана втрата нею багатьох функцій [9].

Тому доцільним виявилося дослідити деякі з вищевказаних показників саме у цьому органі (табл. 2). Після ураження щурів тетрахлорметаном у печінці зростає вміст ТБК-АП у 2,5 раза. Доза рідкого екстрату 0,2 мл/кг позитивно впливала на цей показник, знижуючи його вміст практично удвічі, порівняно з групою тварин із контрольною патологією. Інші використані нами дози виявилися неефективними.

Таблиця 2. Вплив різних доз рідкого екстракту ліщини звичайної на біохімічні показники у печінці щурів,

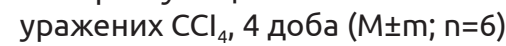

\begin{tabular}{|c|c|c|c|c|}
\hline \multirow[b]{2}{*}{ Група тварин } & \multicolumn{4}{|c|}{ Показники } \\
\hline & $\begin{array}{c}\text { ТБК-АП, } \\
\text { мКмоль/Кг }\end{array}$ & $\begin{array}{c}\text { KT } \\
\text { МКат/K厂 }\end{array}$ & $\begin{array}{c}\text { АлАТ } \\
\text { мкмоль/Кг год }\end{array}$ & $\begin{array}{c}\text { АсАТ } \\
\text { мкмоль/Кг год }\end{array}$ \\
\hline IK & $5,72 \pm 0,21$ & $7,18 \pm 0,42$ & $0,52 \pm 0,017$ & $0,34 \pm 0,016$ \\
\hline КП & $14,35 \pm 0,65 *$ & $4,25 \pm 0,17$ & $0,24 \pm 0,012 *$ & $0,24 \pm 0,011 *$ \\
\hline КП+0,05 мл/Кг РЕ & $12,64 \pm 0,62$ & $4,75 \pm 0,20$ & $0,27 \pm 0,013$ & $0,25 \pm 0,012$ \\
\hline КП+0,1 мл/Кг РЕ & $12,37 \pm 0,45$ & $5,02 \pm 0,22$ & $0,28 \pm 0,016$ & $0,27 \pm 0,011$ \\
\hline КП+0,2 мл/Кг РЕ & $7,38 \pm 0,35 * *$ & $6,87 \pm 0,25 * *$ & $0,42 \pm 0,018 * *$ & $0,31 \pm 0,014 * *$ \\
\hline
\end{tabular}

Примітки: 1. * - вірогідні зміни між інтактними та ураженими тваринами; 2. ** - вірогідні зміни між ураженими та лікованими тваринами.

При дослідженні активності КТ у печінці ми відмітили ії зниження. Очевидно, що ураження тетрахлорметаном, який має гепатотропну дію, призвело до пригнічення білковосинтезувальної функції цього органа, адже всі ензими, маючи протеїнову природу, синтезуються саме в печінці. На 4 добу розвитку токсичного гепатиту активність КТ у ній знизилась в 1,7 раза. Рідкий екстракт в дозі 0,2 мл/кг наблизив цей показник до рівня норми й на 4,3 \% відрізнявся від неї.

Наступним етапом наших досліджень стало дослідження активності амінотрансфераз у печінці в умовах змодельованої патології. Ми виявили, що активність АлАТ у печінці знизилась у 2,2 раза, АсАТ - у 1,4 раза (табл. 2).

Очевидно, це є однією із причин збільшення активності амінотрансфераз у сироватці крові, а також зниження активності білковосинтезувальної функції печінки, оскільки уражений гепатоцит неспроможний до синтезу нових протеїнів.

У наших експериментах ми використали рідкий екстракт ліщини звичайної листя й дослідили його вплив на показники цитолізу клітинних мембран.
Досліджувана субстанція ефективно впливала на показник АсАТ при застосуванні у дозі 0,2 мл/кг. Цей показник на 4 добу гепатиту в печінці підви-

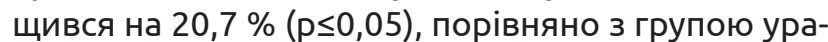
жених щурів, та мало чим відрізнявся від інтактного контролю.

Активність АлАТ після ураження знизилась на 54 \% у печінці щурів і після застосування екстракту в дозі 0,2 мл/кг вона підвищилась в 1,75 раза. Дози 0,05 мл/кг та 0,1 мл/кг маси тіла щурів виявились неефективними.

Показники активності амінотрансфераз в ураженому організмі після використання рідкого екстракту вказують на цитопротекторні властивості вказаної лікарської субстанції, ефективність якої, очевидно, реалізується через антиоксидантні властивості.

Висновки. Проведені дослідження дозволили рекомендувати дозу рідкого екстракту 0,2 мл/кг маси тварин як умовно терапевтичну, оскільки після її потрапляння до організму уражених тетрахлорметаном тварин пригнічуються процеси вільнорадикального окиснення, відновлюється активність антиоксидантної системи. Все це при- 
Огляди літератури, оригінальні дослідження, погляд на проблему, випадок з практики, короткі повідомлення водить до відновлення проникності плазматичних мембран гепатоцитів та еритроцитів.

Отримані результати підтверджують прояв антиоксидантних та мембранопротекторних властивостей рідкого екстракту ліщини звичайної листя у запропонованій дозі.

Перспективи подальших досліджень полягають у подальшому вивченні фармакологічної активності даного оригінального лікарського засобу - рідкого екстракту ліщини звичайної листя як перспективного засобу для профілактики та лікування патології печінки.

\section{ЛІТЕРАТУРА}

1. Державна фармакопея України / ДП «Український науковий фармакопейний центр якості лікарських засобів»; 2-е вид., 3 допов. - Х. : Державне підприємство «Український науковий фармакопейний центр якості лікарських засобів», 2018. - 352 с.

2. Бєленічев І. Ф. Антиоксидантна система захисту організму (огляд) / І. Ф. Бєленічев, Є. Л. Левицький, Ю. І. Губський // Современные проблеми токсикологии. - 2002. - № 3. - С. 24-29.

3. Влізло В. В. Лабораторні методи досліджень у біології, тваринництві та ветеринарній медицині : довідник / В. В. Влізло, Р. С. Федорук, І. Б. Ратич. - Львів : СПОЛОМ, 2012. - 764 с.

4. Вялов С. С. Синдром цитолиза в гастроэнтерологии: тактика ведения пациентов в общей практике / С. С. Вялов // Гастроэнтерология : приложение к журн. Consilium Medicum. - 2013. - № 1. - C. 42-48.

5. Галенова Т. І. Зміна біохімічного профілю організму за умов тетрахлорметан-індукованого ураження печінки у щурів / Т. І. Галенова, Н. Г. Ракша, О. М. Савчук // Scienc Rise: Biological Science. - 2016. - № 2(2). - C. 47-54.

6. Королюк М. А. Метод определения активности каталазы / М. А. Королюк, Л. М. Майорова, В. Э. Токарев // Лабораторное дело. - 1988. - № 1. - С. 16-19.

7. Линда О. С. Вплив настойки з хости ланцетолистої на показники цитолізу клітинних мембран у щурів, уражених тетрахлорметаном / О. С. Линда, Л. С. Фіра, І. П. Кузьмак // Український біофармацевтичний журнал. -2017 . - № 6 (53). - С. 56-60.

8. Лущак В. І. Показники оксидативного стресу. Тіобарбітурактивні продукти і карбонільні групи білків / В. І. Лущак, Т. В. Багнюкова, О. В. Лущак // Укр. біохім. журн. - 2004. - Т. 76, № 6. - С. 136-141.

9. Роль печінки у підтриманні гомеостазу організму людини за фізіологічних та патологічних умов / Б. Г. Макар, Т. В. Процак, Н. І. Гаїна, Т. М. Антоняк // Вісник проблем біології і медицини. - 2012. - № 3. - С. 15-17.

10. Тогайбаев А. А. Способ диагностики эндогенной интоксикации / А. А. Тогайбаев, А. В. Кургузкин, И. В. Рикун // Лаб. дело. - 1988. - № 9. - С. 22-24.

11. Федченкова Ю. А. Фармакогностичне дослідження рослин родин березові, гарбузові, глухокропивові та створення субстанцій на їх основі : автореферат дис. на здобуття наукового ступеня д-ра фармацевт. наук, спец. : 15.00 .02 - фармацевтична хімія і фармакогнозія / Федченкова Ю. А. - Х. : НФаУ, 2018. - 41 с.

12. Ciarmiello L. F. Analysis of different European hazelnut (Corylus avellana L.) cultivars: Authentication, phenotypic features, and phenolic profiles / L. F. Ciarmiello // J. Agric. Food Chem. - 2014. - No. 62. - P. 6236-6246.

13. Antioxidant activity and phenolic composition of Corylus colurna / E. Riethmüller, G. Tóth, A. Alberti [et al.] // Nat. Prod. Commun. - 2014. - Vol. 9 (5). - P. 679-682.

14. Antioxidant properties and UPLC-MS/MS profiling of phenolics in jacquemont's hazelnut kernels (Corylus jacquemontii) and its byproducts from western Himalaya / A. Kumar, P. Kumar, R. Koundal, V. K. Agnihotri // J. Food Sci. Technol. - 2016. - No. 53 (9). - P. 3522-3531.

15. Yuan B. Extraction, identification, and quantification of antioxidant phenolics from hazelnut (Corylus avellana L.) shells / B. Yuan // Food Chem. - 2018. - No. 244. - P. 7-15.

16. First characterisation of flavonoid- and diarylheptanoid-type antioxidant phenolics in Corylus maxima by HPLC-DAD-ESI-MS / E. Riethmüller, G. Tóth, Á. Alberti [et al.] // J. Pharm. Biomed. Anal. - 2015. - Vol. 107. - P. 159167. DOI: $10.1016 / \mathrm{j}$

17. Gross D. Ethics in Animal-Based Research / D. Gross, R. Tolba // Eur. Surg. Res. - 2015. - Vol. 55, Issue 1-2. - P. 4357. DOI: 10.1159/000377721.

18. Hazelnut (Corylus avellana L.) kernels as a source of antioxidants and their potential in relation to other nuts. / T. Delgado, R. Malheiro, J. A. Pereira, E. Ramalhosa // Ind. Crops Prod. - 2010. - No. 32. - P. 621-626.

19. HPLC-DPPH Screening Method for Evaluation of Antioxidant Compounds in Corylus Species / E. Riethmüller, A. Könczöl, D. Szakál c // Nat. Prod. Commun. 2016. - Vol. 11 (5). - P. 641-644.

20. Aspartate Aminotransferase (AST/GOT) and Alanine Aminotransferase (ALT/GPT) / X. J. Huang, Y. K. Choi, H. S. Im [et al.] // Detection Techniques. Sensors (Basel). 2006. - Vol. 6 (7). - P. 756-782.

21. Okeh U. Statistical problems in medical research / U. Okeh // East. Afr. J. Public. Health. - 2009. - Vol. 6, No. 1. P. 1-7.

22. Phenolic profiles and antioxidant activity of Turkish Tombul hazelnut samples (natural, roasted, and roasted hazelnut skin) / E. Pelvan, E. Ö. Olgun, A. Karadağ, C. Alasalvar // Food Chem. - 2018. - Vol. 244. - P.102-108. DOI: 10.1016/j

23. Roasting affects phenolic composition and antioxidative activity of hazelnuts (Corylus avellana L.) / V. Schmitzer, A. Slatnar, R. Veberic [et al.] // J. Food Sci. 2011. - Vol. 76 (1). - P. 14-19. DOI: 10.1111/j. 
Огляди літератури, оригінальні дослідження, погляд на проблему, випадок з практики, короткі повідомлення REFERENCES

1. (2018). Derzhavna farmakopeia Ukrainy / DP "Ukrainskyi naukovyi farmakopeinyi tsentr yakosti likarskykh zasobiv". 2-e vyd., 3 dopov. [State Pharmacopoeia of Ukraine/SE "Ukrainian Scientific Pharmacopoeial Center for Medicinal Products Quality"; 2nd ed., 3 suppl]. Kharkiv: Derzhavne pidpryiemstvo "Ukrainskyi naukovyi farmakopeinyi tsentr yakosti likarskykh zasobiv" [in Ukrainian].

2. Bielenichev, I.F., Levytskyi, Ye.L. \& Hubskyi, Ye.I. (2002). Antyoksydantna systema zakhystu orhanizmu (ohliad) [Antioxidant system of protection of the organism (review)]. Sovremennyye problemy toksikologii - Current Problems of Toxicology, 3, 24-29 [in Ukrainian].

3. Vlizlo, V.V., Fedoruk, R.S. \& Ratich, I.B. (2012). Laboratorni metody doslidzhen u biolohii, tvarynnytstvi ta veterynarnii medytsyni: dovidnyk [Laboratory research methods in biology, animal husbandry and veterinary medicine: reference book]. Lviv: SPOLOM [in Ukrainian].

4. Vyalov, S.S. (2013). Sindrom tsitoliza v gastroenterologii: taktika vedeniya patsiyentov v obshchey praktike [Syndrome of cytolysis in gastroenterology: management tactics of patients in general practice]. Gastroenterologiya: prilozheniye k zhurn. Consilium Medicum - Gastroenterology: An Appendix to the Journal. Consilium Medicum, 1, 4248 [in Russian].

5. Halenova, T.I., Raksha, N.H., \& Savchuk, O.M. (2016). Zmina biokhimichnoho profilyu orhanizmu za umov tetrakhlormetan-indukovanoho urazhennia pechinky u shchuriv [Changes in the biochemical profile of the organism under conditions of tetrachloromethane-induced liver damage in rats]. Science Rise: Biological Science, 2 (2), 47-54 [in Ukrainian].

6. Korolyuk, M.A., Ivanova, L.I. \& Mayorova, I.G. (1988). Metod opredeleniya aktivnosti katalazy [Method for determining the activity of catalase]. Lab. Delo - Lab. Business, 1, 16-19 [in Russian].

7. Lynda, O.S., Fira, L.S. \& Kuzmak, I.P. (2017). Vplyv nastoiky z khosty lantsetolystoi na pokaznyky tsytolizu klitynnykh membran u shchuriv, urazhenykh tetrakhlormetanom [Influence of tincture from host lanceolate on indicators of cell membrane cytolysis in rats affected by tetrachloromethane]. Ukrainskyi biofarmatsevtychnyi zhurnal Ukrainian Biopharmaceutical Journal, 6 (53), 56-60 [in Ukrainian].

8. Lushchak, V.I., Bahniukova, T.V. \& Lushchak, O.V. (2004). Pokaznyky oksydatyvnoho stresu. Tiobarbituraktyvni produkty i karbonilni hrupy bilkiv [Indicators of oxidative stress. Thiobarbiturative products and carbonyl groups of proteins]. Ukrainskyi biokhimichnyi zhurnal - Ukrainian Biochemical Journal, 76 (6), 136-141 [in Ukrainian].

9. Makar, B.H., Protsak, T.V., \& Haina, N.I., Antoniak, T.M. (2012). Rol pechinky u pidtrymanni homeostazu orhanizmu liudyny za fiziolohichnykh ta patolohichnykh umov [The role of the liver in maintaining homeostasis of the human body under physiological and pathological condi- tions]. Visnyk problem biolohii i medytsyny - Bulletin of Problems of Biology and Medicine, 3, 15-17 [in Ukrainian].

10. Togaybaev, A.A., Kurguzkin, A.V., \& Rikun, I. (1988). Sposob diagnostiki endogennoy intoksikatsii [A method for the diagnosis of endogenous intoxication]. Lab. delo. Lab. Business. 9, 22-24 [in Russian].

11. Fedchenkova, Yu.A. (2018). Farmakohnostychne doslidzhennia roslyn rodyn berezovi, harbuzovi, hlukhokropyvovi ta stvorennia substantsii na yikh osnovi: Doctor's Extended abstract. Kharkiv: NFaU [in Ukrainian].

12. Ciarmiello, L.F. (2014). Analysis of different European hazelnut (Corylus avellana L.) cultivars: Authentication, phenotypic features, and phenolic profiles. J. Agric. Food Chem., 62, 6236-6246.

13. Riethmüller, E., Tóth, G., \& Alberti, A. (2014). Antioxidant activity and phenolic composition of Corylus colurna. Nat. Prod. Commun., 9 (5), 679-682.

14. Kumar, A., Kumar, P., Koundal, R., \& Agnihotri, V.K. (2016). Agnihotri antioxidant properties and UPLC-MS/MS profiling of phenolics in jacquemont's hazelnut kernels (Corylus jacquemontii) and its byproducts from western Himalaya. J. Food Sci. Technol., 53 (9), 3522-3531.

15. Yuan, B. (2018). Extraction, identification, and quantification of antioxidant phenolics from hazelnut (Corylus avellana L.) shells. Food Chem., 244, 7-15.

16. Riethmüller, E., Tóth, G., \& Alberti, Á. (2015). First characterisation of flavonoid- and diarylheptanoid-type antioxidant phenolics in Corylus maxima by HPLC-DAD-ESIMS. J. Pharm. Biomed. Anal., 107, 159-167. doi: 10.1016/j

17. Gross, D., \& Tolba, R. (2015). Ethics in animalbased research. Eur. Surg. Res.,1-2, 43-57. doi: 10.1159/000377721.

18. Delgado, T., Malheiro, R., Pereira, J.A., \& Ramalhosa, E. (2010). Hazelnut (Corylus avellana L.) kernels as a source of antioxidants and their potential in relation to other nuts. Ind. Crops Prod., 32, 621-626.

19. Riethmüller, E., Könczöl, A., \& Szakál, D. (2016). HPLC-DPPH Screening Method for Evaluation of Antioxidant Compounds in Corylus Species. Nat. Prod. Commun., $11(5), 641-644$

20. Huang, X.J., Choi, Y.K., Im, H.S., Yarimaga, O., Yoon, E., \& Kim, H.S. (2006). Aspartate aminotransferase (AST/GOT) and alanine aminotransferase (ALT/GPT). Detection Techniques. Sensors (Basel), 6 (7), 756-782.

21. Okeh, U. (2009). Statistical problems in medical research. East. Afr. J. Public. Health., 6 (1), 1-7.

22. Pelvan, E., Olgun, EÖ., Karadağ, A., \& Alasalvar, C. (2018). Phenolic profiles and antioxidant activity of Turkish Tombul hazelnut samples (natural, roasted, and roasted hazelnut skin. Food Chem., 244, 102-108. doi: 10.1016/j

23. Schmitzer, V., Slatnar, A., \& Veberic, R. (2011). Roasting affects phenolic composition and antioxidative activity of hazelnuts (Corylus avellana L.). J. Food Sci., 76 (1), 14-19. doi: 10.1111/j. 
Огляди літератури, оригінальні дослідження, погляд на проблему, випадок з практики, короткі повідомлення

УСТАНОВЛЕНИЕ ЭФФЕКТИВНОЙ ДОЗЫ ЖИДКОГО ЭКСТРАКТА ЛИСТЬЕВ ЛЕЩИНЫ ОБЫКНОВЕННОЙ И ИССЛЕДОВАНИЕ ЕГО АНТИОКСИДАНТНОЙ АКТИВНОСТИ

\author{
○Ю. А. Федченкова', Л. С. Фира², О. П. Хворост³, К. С. Скребцова
}

${ }^{1}$ Нежинский государственный университет имени Николая Гоголя

${ }^{2}$ Тернопольский национальный медицинский университет имени И. Я. Горбачевского Мз Украины

${ }^{3}$ Национальный фармачевтический университет, Харьков

РЕзЮМЕ. На современном этапе используется значительное количество лекарственных препаратов, способных влиять на окислительные процессы в организме при различных патологических состояниях. Однако поиск новых высокоэффективных и малотоксичных препаратов продолжается. Лещина обыкновенная - распространенное растение отечественной флоры, листья которой широко используются как противовоспалительное и сосудоукрепляющее средство. Актуальным является исследование антиоксидантного действия оригинального отечественного фитосредства - жидкого экстракта листьев лещины обыкновенной.

Цель - установить минимально действующую дозу жидкого экстракта листьев лещины обыкновенной и изучить его антиоксидантные свойства на модели токсического поражения печени крыс.

Материал и методы. Эксперименты проведены на белых крысах-самцах с соблюдением всех правил работы с позвоночными животными. Токсическое поражение печени моделировали путем введения в организм крыс 50 \% раствора тетрахлорметана в дозе 1,0 мл/кг массы тела. Жидкий экстракт из листьев лещины животные получали в дозе 0,05, 0,1 и 0,2 мл/кг массы тела. Развитие оксидативного стресса изучали по содержанию ТБК-активных продуктов, церулоплазмина и каталазной активности. Активность цитологических процессов исследовали по эритроцитарному индексу интоксикации и активности аминотрансфераз в пораженном организме.

Результаты. Установлено, что поражение печени крыс тетрахлорметаном приводит к активации процессов липопероксидации, на что указывает повышение в сыворотке крови и печени животных содержания ТБК-активных продуктов и изменение показателей антиоксидантной системы (повышение содержания церулоплазмина в сыворотке крови и снижение каталазной активности). В условиях поражения повышалась активность аминотрансфераз в сыворотке крови и, соответственно снижалась в печени токсикованных животных, что указывает на цитолиз гепатоцитов после поражения печени крыс тетрахлорметаном.

Применение жидкого экстракта листьев лещины обыкновенной в дозе 0,2 мл/кг эффективнее влияло на исследуемые показатели, приближая их к уровню крыс интактного контроля. Дозы 0,05 и 0,1 мл/кг оказались неэффективными для исследуемых показателей.

Выводы. Установлена минимально действующая доза жидкого экстракта листьев лещины - 0,2 мл/кг массы животных, которая проявила выраженные антиоксидантные свойства в условиях токсического гепатита у крыс.

КЛЮЧЕВЫЕ СЛОВА: условно терапевтическая доза; токсический гепатит; антиоксидантное действие; жидкий экстракт листьев лещины обыкновенной.

\title{
ESTABLISHING AN EFFECTIVE DOSE OF LIQUID EXTRACT OF COMMON HAZEL LEAVES AND STUDY OF ITS ANTIOXIDANT ACTIVITY
}

\author{
○Yu. A. Fedchenkova', L. S. Fira², O. P. Khvorost ${ }^{3}$, K. S. Skrebtsova ${ }^{3}$ \\ ${ }^{1}$ Nizhyn Mykola Hohol State University \\ ${ }^{2}$ I. Horbachevsky Ternopil National Medical University \\ ${ }^{3}$ National University of Pharmacy, Kharkiv
}

SUMMARY. At the present stage, a significant number of drugs are used that can affect the oxidative processes in the body in various pathological conditions. However, the search for new highly effective and low-toxic drugs continues. Common hazel - a common plant of domestic flora, the leaves of which are widely used as anti-inflammatory and vasoconstrictor. Actual is the study of the antioxidant effect of the original domestic phytochemicals - a liquid extract of common hazel leaves.

The aim - to establish the minimum effective dose of the liquid extract of common hazel leaves and to study its antioxidant properties in a model of toxic damage to rat liver.

Material and Methods. The experiments were carried out on white male rats in compliance with all rules for working with vertebrate animals. Toxic liver damage was modeled by introducing into the rats a $50 \%$ solution of carbon tetrachloride in a dose of $1.0 \mathrm{ml} / \mathrm{kg}$ body weight. The animals obtained liquid extract from hazel leaves at a dose of 0.05 , 0.1 and $0.2 \mathrm{ml} / \mathrm{kg}$ body weight. The development of oxidative stress was studied by the content of TBA-active products, ceruloplasmin and catalase activity. The activity of cytological processes was investigated by the erythrocyte index of intoxication and the activity of aminotransferases in the affected body.

Results. It was found that damage to the liver of rats with tetrachloromethane leads to the activation of lipid peroxidation processes, as indicated by an increase in the serum of animals and liver of TBA-active products and changes 
Огляди літератури, оригінальні дослідження, погляд на проблему, випадок з практики, короткі повідомлення in the antioxidant system (increase in ceruloplasmin in serum and a decrease in catalase activity). Under the conditions of the lesion, the activity of aminotransferases in blood serum increased and, accordingly, decreased in the liver of toxic animals, which indicates cytolysis of hepatocytes after liver damage to rats with carbon tetrachloride.

The use of a liquid extract of common hazel leaves at a dose of $0.2 \mathrm{ml} / \mathrm{kg}$ showed an effect on the studied parameters, bringing them closer to the level of rats of intact control. Doses of 0.05 and $0.1 \mathrm{ml} / \mathrm{kg}$ were ineffective for the studied parameters.

Conclusions. The minimum effective dose of the liquid extract of hazel leaves was found to be $0.2 \mathrm{ml} / \mathrm{kg}$ of animal weight, which showed pronounced antioxidant properties in toxic hepatitis in rats.

KEY WORDS: conditionally therapeutic dose; toxic hepatitis; antioxidant effect; liquid extract of common hazel leaves.

Отримано 24.11.2019 